Article

\title{
Expression of Anti-Lipopolysaccharide Factor Isoform 3 in Chlamydomonas reinhardtii Showing High Antimicrobial Activity
}

\author{
Anguo Li ${ }^{1}$, Ruihao Huang ${ }^{1}$, Chaogang Wang ${ }^{1,2,3, *}$, Qunju $\mathrm{Hu}^{1,2}{ }^{1,} \mathrm{Hui} \mathrm{Li}^{1,2,3}$ and $\mathrm{Xiao} \mathrm{Li}^{4}$ \\ 1 Shenzhen Key Laboratory of Marine Bioresource \& Eco-Environmental Science, College of Life Sciences \\ and Oceanography, Shenzhen University, Shenzhen 518060, China; lianguo2018@email.szu.edu.cn (A.L.); \\ huangruihao2018@email.szu.edu.cn (R.H.); huqunju@szu.edu.cn (Q.H.); lihui80@szu.edu.cn (H.L.) \\ 2 Guangdong Technology Research Center for Marine Algal Bioengineering, College of Life Sciences \\ and Oceanography, Shenzhen University, Shenzhen 518060, China \\ 3 Guangdong Provincial Key Laboratory for Plant Epigenetics, College of Life Sciences and Oceanography, \\ Shenzhen University, Shenzhen 518060, China \\ 4 Department of Journal of Shenzhen University Science and Engineering, Shenzhen University, \\ Shenzhen 518060, China; lixiao@szu.edu.cn \\ * Correspondence: charlesw@szu.edu.cn
}

Citation: Li, A.; Huang, R.; Wang, C.; $\mathrm{Hu}, \mathrm{Q}$; Li, H.; Li, X. Expression of Anti-Lipopolysaccharide Factor Isoform 3 in Chlamydomonas reinhardtii Showing High Antimicrobial Activity. Mar. Drugs 2021, 19, 239. https:// doi.org/10.3390/md19050239

Academic Editors: Xavier Just-Baringo and Sara M. Soto

Received: 29 March 2021

Accepted: 20 April 2021

Published: 23 April 2021

Publisher's Note: MDPI stays neutral with regard to jurisdictional claims in published maps and institutional affiliations.

Copyright: () 2021 by the authors. Licensee MDPI, Basel, Switzerland. This article is an open access article distributed under the terms and conditions of the Creative Commons Attribution (CC BY) license (https:// creativecommons.org/licenses/by/ $4.0 /)$.

\begin{abstract}
Antimicrobial peptides are a class of proteins with antibacterial functions. In this study, the anti-lipopolysaccharide factor isoform 3 gene (ALFPm3), encoding an antimicrobial peptide from Penaeus monodon with a super activity was expressed in Chlamydomonas reinhardtii, which would develop a microalga strain that can be used for the antimicrobial peptide production. To construct the expression cluster, namely pH2A-Pm3, the codon optimized ALFPm3 gene was fused with the ble reporter by $2 \mathrm{~A}$ peptide and inserted into $\mathrm{pH} 124$ vector. The glass-bead method was performed to transform $\mathrm{pH} 2 \mathrm{~A}-\mathrm{Pm} 3$ into C. reinhardtii CC-849. In addition to $8 \mu \mathrm{g} / \mathrm{mL}$ zeocin resistance selection, the $C$. reinhardtii transformants were further confirmed by genomic PCR and RT-PCR. Western blot analysis showed that the C. reinhardtii-derived ALFPm3 (cALFPm3) was successfully expressed in C. reinhardtii transformants and accounted for $0.35 \%$ of the total soluble protein (TSP). Furthermore, the results of antibacterial assay revealed that the cALFPm 3 could significantly inhibit the growth of a variety of bacteria, including both Gram-negative bacteria and Gram-positive bacteria at a concentration of $0.77 \mu \mathrm{M}$. Especially, the inhibition could last longer than $24 \mathrm{~h}$, which performed better than ampicillin. Hence, this study successfully developed a transgenic C. reinhardtii strain, which can produce the active ALFPm 3 driven from P. monodon, providing a potential strategy to use C. reinhardtii as the cell factory to produce antimicrobial peptides.
\end{abstract}

Keywords: antimicrobial peptide; anti-lipopolysaccharide factor isoform 3; Chlamydomonas reinhardtii; heterologous expression; antimicrobial assay

\section{Introduction}

Nowadays, people are suffering from the multidrug-resistant (MDR) microorganisms caused by the overuse of antibiotics [1-3]. The demand of finding alternatives to replace traditional antibiotics is increasing. Antimicrobial peptides (AMPs) are one of the promising candidates due to their positive effect on killing drug-resistant microorganisms [4,5]. AMPs are peptides consisting of 5-300 amino acids and are widely distributed in various organisms [6-9]. In general, AMPs own a broad-spectrum antimicrobial activity [10,11], anti-cancer cell activity [12,13], and antiviral activity [14]. As one of the known AMPs, anti-lipopolysaccharide factors (ALFs) were firstly identified from the hemocytes of Limulus polyphemus [15]. ALFs have the lipopolysaccharide (LPS) binding domain (LBD), which can bind to LPS to exhibit antimicrobial activity. To date, several ALFs have been identified from Penaeus monodon [16-18]. Among them, ALFPm3 has a wider anti-bacteria spectrum 
than other ALFs [19-22]. AMPs are commonly produced in Escherichia coli [23-27] or Pichia pastoris $[28,29]$ due to its low yield in natural sources. However, the ALFPm3 could hardly be expressed in E. coli possibly because of its strong antimicrobial activity [20]. It was reported that the ALFPm3 gene could be expressed in P. pastoris and its protein extracts showed a broad-spectrum antimicrobial activity, especially on Gram-negative bacteria [30]. However, there were still several defects, such as the low yield, higher cost, $\mathrm{CO}_{2}$ releasement, and the challenge of rALFPm3 extraction and purification. Additionally, $P$. pastoris expression system will cause excessive glycosylation, which would restrain the activity of ALFPm3 [31-34], whereas as a model organism of unicellular green microalgae, Chlamydomonas reinhardtii can overcome these problems. Currently, C. reinhardtii has established the stable genetic transformation systems in nucleus, chloroplast, and mitochondrion [35-39]. The nuclear genome of C. reinhardtii has been sequenced [40] and many mutants have been created for molecular biology research or heterologous expression of useful proteins. To date, a lot of functional enzymes [41], antigens [42], antibodies [43], and vaccines [44] have been successfully expressed in C. reinhardtii. As a platform for protein production, C. reinhardtii has certain advantages, including rapid growth, capability of protein post-translational processing, and expressing a large amount of foreign protein in chloroplasts. Furthermore, it is capable of photoautotrophy using low-cost medium and it would not release environment- or human-unfriendly metabolites and endotoxins [45-47].

Considering the benefits of using chlamy to produce AMPs, it would be attractive if we can produce ALFPm3 in C. reinhardtii. In this study, the nucleotides of ALFPm3 gene were optimized according to the codon bias of $C$. reinhardtii and fused with the ble gene mediated by FMDV self-cleavage peptide $2 \mathrm{~A}$ sequence, and then introduced into $C$. reinhardtii by a glass-bead method. Transformants were screened through zeocin resistance, confirmed by PCR detection, and evaluated by antimicrobial activity analysis. Our results showed that ALFPm3 could be efficiently expressed in transgenic chlamy. It is more important that extracts from transgenic chlamy exhibited a strong antimicrobial activity to bacteria, including some pathogenic bacteria and its performance even better than ampicillin. Our results demonstrated that $C$. reinhardtii is suitable for AMPs production, showing its potentiality to be used as a replacement of antibiotics on aquaculture.

\section{Results}

\subsection{The Design of ALFPm3 Expression Cassette}

The coding sequence of ALFPm3 gene from P. monodon (Genbank accession: JQ256520) was optimized according to the codon bias of $C$. reinhardtii. The signal peptide of ALFPm3 composed of 25 amino-acid residues in its N-terminal was removed. After optimization, the GC content of $A L F P m 3$ gene was increased from $55.89 \%$ to $68.37 \%$ (Figure 1). The ble gene was fused to the N-terminal of optimized ALFPm3 gene by Foot and Mouth Disease Virus (FMDV) self-cleavage 2A peptide. FMDV 2A peptide can cleavage between Glycine and Proline to form two independent peptides (Figure 2). Moreover, a $6 \times$ His tag was added to the ALFPm 3 for protein detection. The designed ALFPm3 gene expression cassette was then inserted into the $\mathrm{pH} 124$ vector resulting in the $\mathrm{pH} 2 \mathrm{~A}-\mathrm{Pm} 3$ plasmid (Figure 3). 


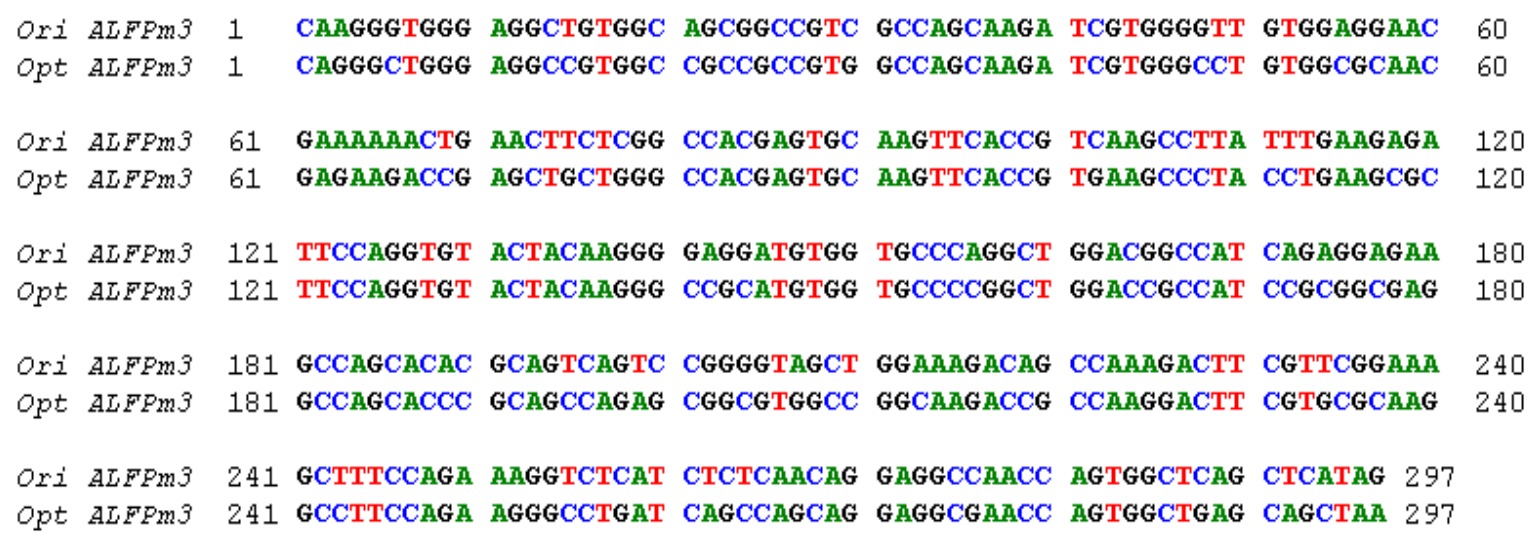

Figure 1. The alignment between the original and codon-optimized ALFPm3 gene. Ori ALFPm3 refers to the original $A L F P m 3$ gene, while opt ALFPm3 refers to the optimized ALFPm3 gene.

\begin{tabular}{|c|c|c|c|c|}
\hline 1 & MARHGQADQR & RS GAHRARRR & R S G R V D R P A & RVLPGLRGGR \\
\hline 41 & L R R C G P R RD & PVHQRGPGPG & PVVPDNTLAW & VWV R GLDE L Y \\
\hline 81 & AEWSEVVSTN & FRDASGPAMT & E I GEQPWGRE & FALRDPAGNC \\
\hline 121 & VHFVAEEQD $\underline{L}$ & LAIHPTEARH & KQK I VAPVKQ & TLNFDLLKLA \\
\hline 161 & GDVESNP GPH & H H H HQ GWEA & VAAAVASKIV & GLWRNEKTEL \\
\hline 201 & LGHECKFTVK & PYLKRFQVYY & K GRMWC P GWT & A IRGEASTRS \\
\hline 241 & Q S GVAGKTAK & DFVRKAFQKG & LI SQQEANQW & L S S 273 \\
\hline
\end{tabular}

Figure 2. The amino acid sequence of the Ble-2A-Pm3-fused protein. The FMDV 2A sequence has been underlined and the cleavage site is preceded by glycine and proline, which is shown with an asterisk.

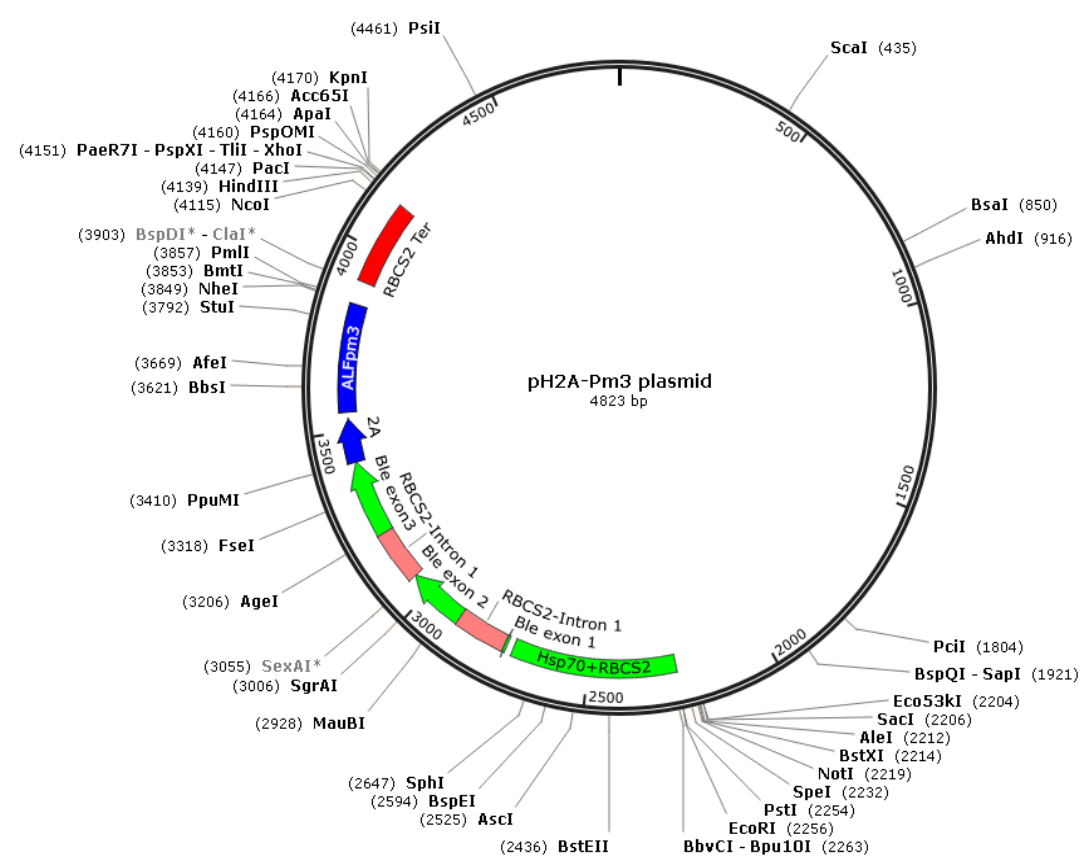

Figure 3. The sketch map of the $\mathrm{pH} 2 \mathrm{~A}-\mathrm{Pm} 3$ plasmid. The restriction sites and their positions are indicated in this figure. 


\subsection{The Screening of Transgenic C. reinhardtii}

The pH2A-Pm3 plasmid was introduced into C. reinhardtii using the glass-bead method. After 2 weeks of recovery, the green colonies were visible and transferred to new TAP agar medium containing $8 \mu \mathrm{g} / \mathrm{mL}$ zeocin and $100 \mu \mathrm{g} / \mathrm{mL}$ ampicillin. Here, more than 200 colonies were obtained and the transformation frequency was $3 \times 10^{-6}$. Later, genomic PCR and RT-PCR targeting at both ble and ALFPm3 were conducted to screen positive transformants. PCR results suggested that the non-transgenic $C$. reinhardtii generated no target bands. The specific bands representing the ble and ALFPm3 genes, respectively, were found in positive transformants, contributing to the positive ratio of $27.27 \%$ at the genomic level (Figure 4A). Moreover, the Ble-2A-Pm3-fused expression cassette could be detected in genomic DNA, too (Figure 4B). Furthermore, both optimized ALFPm3 gene and Ble-2A-Pm3-fused gene in positive transformants were detected in the transcription level (Figure 5). Finally, more than 50 positive transformants were evidenced at both a genomic and transcriptional level and named T-2APm3.

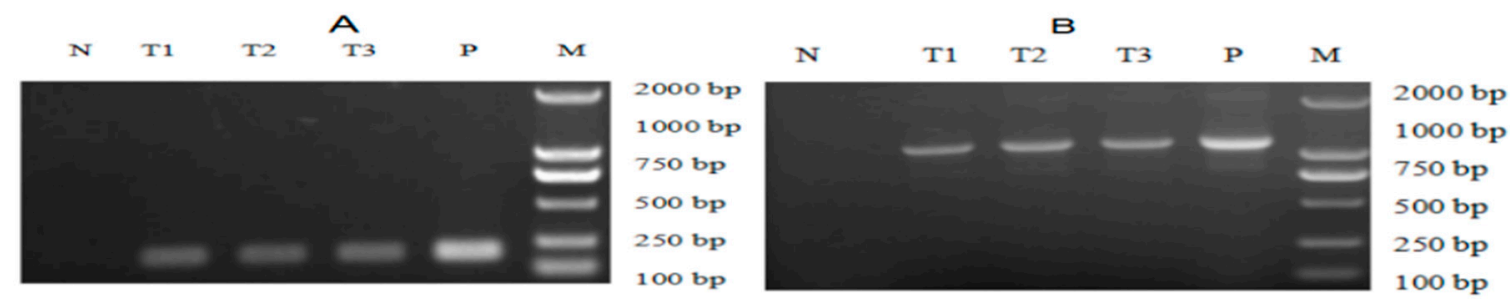

Figure 4. The genomic PCR analysis of transgenic Chlamydomonas. (A) PCR analysis for the ALFPm3 gene. (B) PCR analysis for Ble-2A-Pm3-fused gene. N: negative control, P: positive control, T1 to T3: transgenic Chlamydomonas. M: DL 2000 DNA ladder marker.
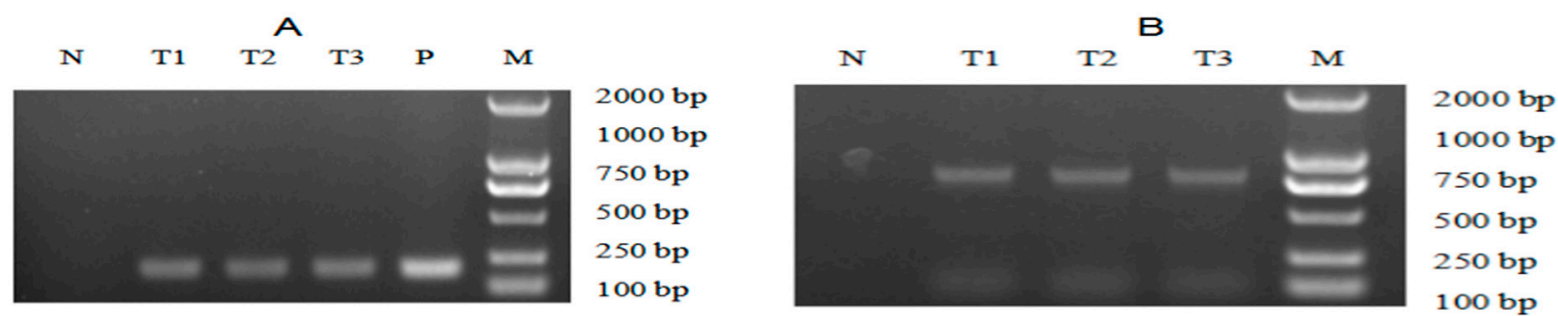

Figure 5. The RT-PCR analysis of transgenic Chlamydomonas. (A) RT-PCR analysis for the ALFPm3 gene. (B) RT-PCR analysis for the Ble-2A-Pm3-fused gene. N: negative control, P: positive control, T1 to T3: transgenic Chlamydomonas. M: DL 2000 DNA ladder marker.

\subsection{The Analysis of ALFPm3 Protein Production in Transgenic C. reinhardtii}

The ALFPm3 peptide with $6 \times$ His tag could be detected by immunoblot using antiHis antibody from total soluble protein (TSP) extracted from T-2APm3 transformants (Figure 6). The molecular weight of ALFPm3 protein was about $12 \mathrm{kD}$, and the fused protein of BLE-2A-ALFPm3 was $30.64 \mathrm{kD}$. Our results indicated that the ALFPm3 could separate from BLE-2A-ALFPm3-fused protein by the self-cleavage of FMDV 2A peptide and accounted for approximate $0.35 \%$ of the TSP, demonstrating that the ALFPm3 gene was successfully expressed in C. reinhardtii. 


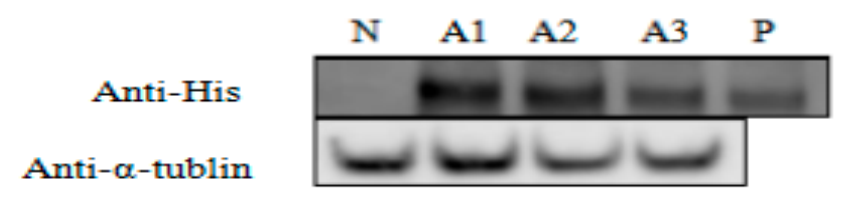

Figure 6. The immunoblot analysis of the ALFPm3 derived from C. reinhardtii. Anti-His Tag: protein extracts incubated with mouse anti-His tag antibody for detecting His tag protein. Anti- $\alpha$-tublin: protein extracts incubated with mouse anti- $\alpha$-tublin antibody for detecting $\alpha$-tublin. $N$ : negative control, P: positive control, a protein with $6 \times$ His tag expressed by E. coli with a concentration of 3.4 $\mu \mathrm{g} / \mathrm{mL}$. A1 to A3: transgenic Chlamydomonas.

\subsection{The Expression Analysis of ALFPm3 Gene in C. reinhardtii}

By comparing the growth curves of T-2APm3 and wild-type, we found that the growth curve of T-2APm3 was identical to that of wild-type (Figure 7), showing that the introduction of the ALFPm3 gene did not affect the normal growth of $C$. reinhardtii. After 6 months of cultivation, ALFPm3 gene did not lose or silence, indicating that the target gene could be stably expressed in $C$. reinhardtii (Figure 8). Moreover, heat shock significantly increased the transcription of the ALFPm3 gene, while the high light increased slightly (Figure 9).

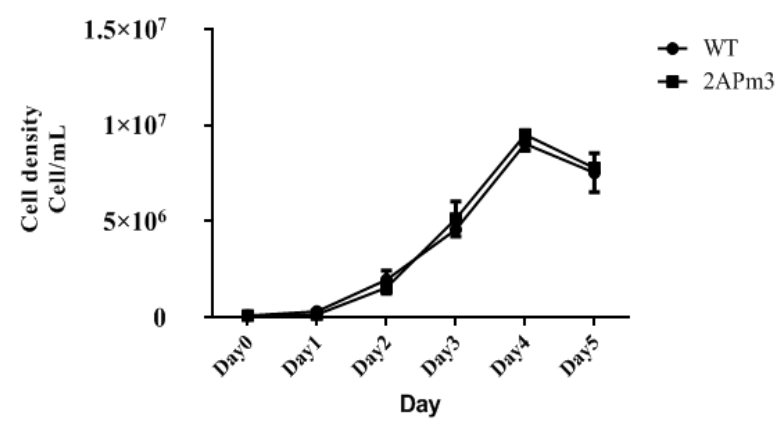

Figure 7. The growth curve of wild type and transgenic chlamydomonas T-2APm3. WT, C. reinhardtii CC-849. 2APm3, transgenic chlamydomonas T-2APm3.

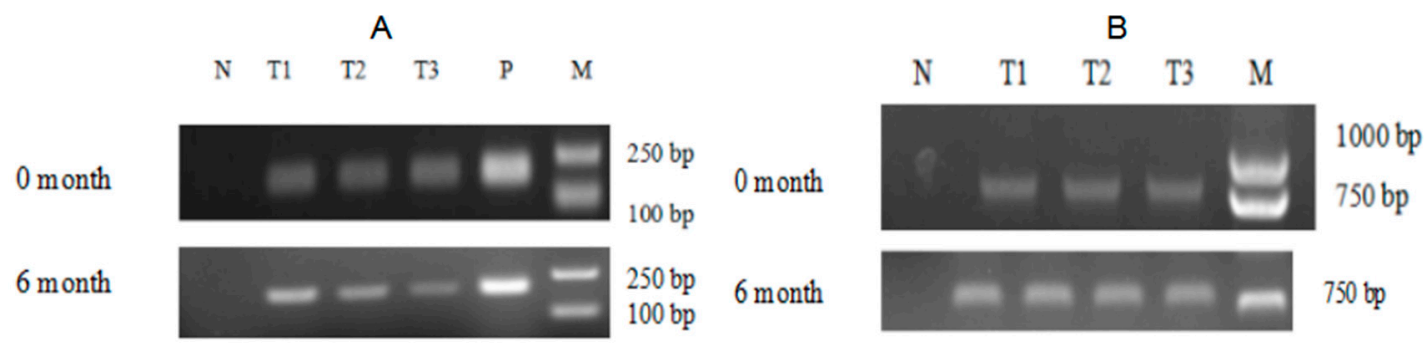

Figure 8. The analysis of ALFPm3 in transgenic Chlamydomonas after 6-month cultivation. (A) genomic PCR analysis of the ALFPm3 gene. (B) RT-PCR analysis of the ALFPm3 gene. N: negative control, P: positive control, T1 to T3: transgenic Chlamydomonas. M: DL 2000 DNA ladder marker.

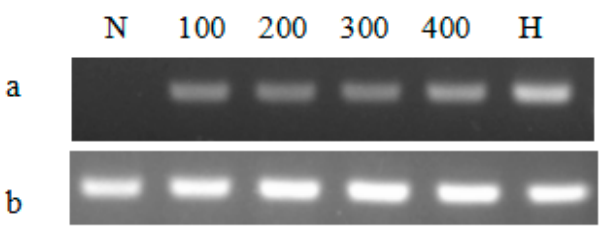

Figure 9. The semi-quantitative RT-PCR analysis of the ALFPm3 gene in different cultivation conditions. (a), RT-PCR analysis for the ALFPm3 gene, (b), RT-PCR analysis for $\beta$-actin gene. N: negative control, H: heat shock treatment. 100, 200, 300, and 400 represent 100, 200, 300, and $400 \mu \mathrm{E} \cdot \mathrm{m}^{-2} \cdot \mathrm{s}^{-1}$ light conditions, respectively. 


\section{5. cALFPm3 Showed High Anti-Bacterial Activity}

After small-scale cultivation, TSP containing ALFPm3 peptide was extracted from $\mathrm{T}-2 \mathrm{APm} 3$ transformants to evaluate the anti-bacterial activity. The results showed that the cALFPm 3 at the final concentration of $0.77 \mu \mathrm{M}$ could significantly inhibit the growth of Gram-negative bacteria such as E. coli Top10, Vibrio vulnificus, Vibrio parahaemolyticus, and Vibrio alginolyticus within $12 \mathrm{~h}$ (Figure 10). Notably, the antibacterial rate of cALFPm3 against Gram-negative bacteria was 1.4-7.2 times higher than $5 \mathrm{mg} / \mathrm{mL}$ ampicillin. Those Gram-negative bacteria, except $V$. anguillarum, hardly grew when treated with cALFPm3 within $24 \mathrm{~h}$ (Figure 10). Meanwhile, the inhibition on the Gram-positive bacteria, such as Streptococcus agalactiae, Staphylococcus aureus, and Bacillus sp T2, was also observed within $12 \mathrm{~h}$ (Figure 11). For example, the antibacterial rate of cALFPm 3 against $S$. aureus was 2.3 times higher than $5 \mathrm{mg} / \mathrm{mL}$ ampicillin (Figure 11). The antibacterial activities of cALFPm 3 are superior against both Gram-negative bacteria and Gram-positive bacteria and lasted for over $12 \mathrm{~h}$ at a concentration of $0.77 \mu \mathrm{M}$, which was far beyond the ampicillin (Figures 10 and 11). Hence, our studies provided a promising cALFPm3, which showed a broad antimicrobial spectrum and strong antimicrobial activity.
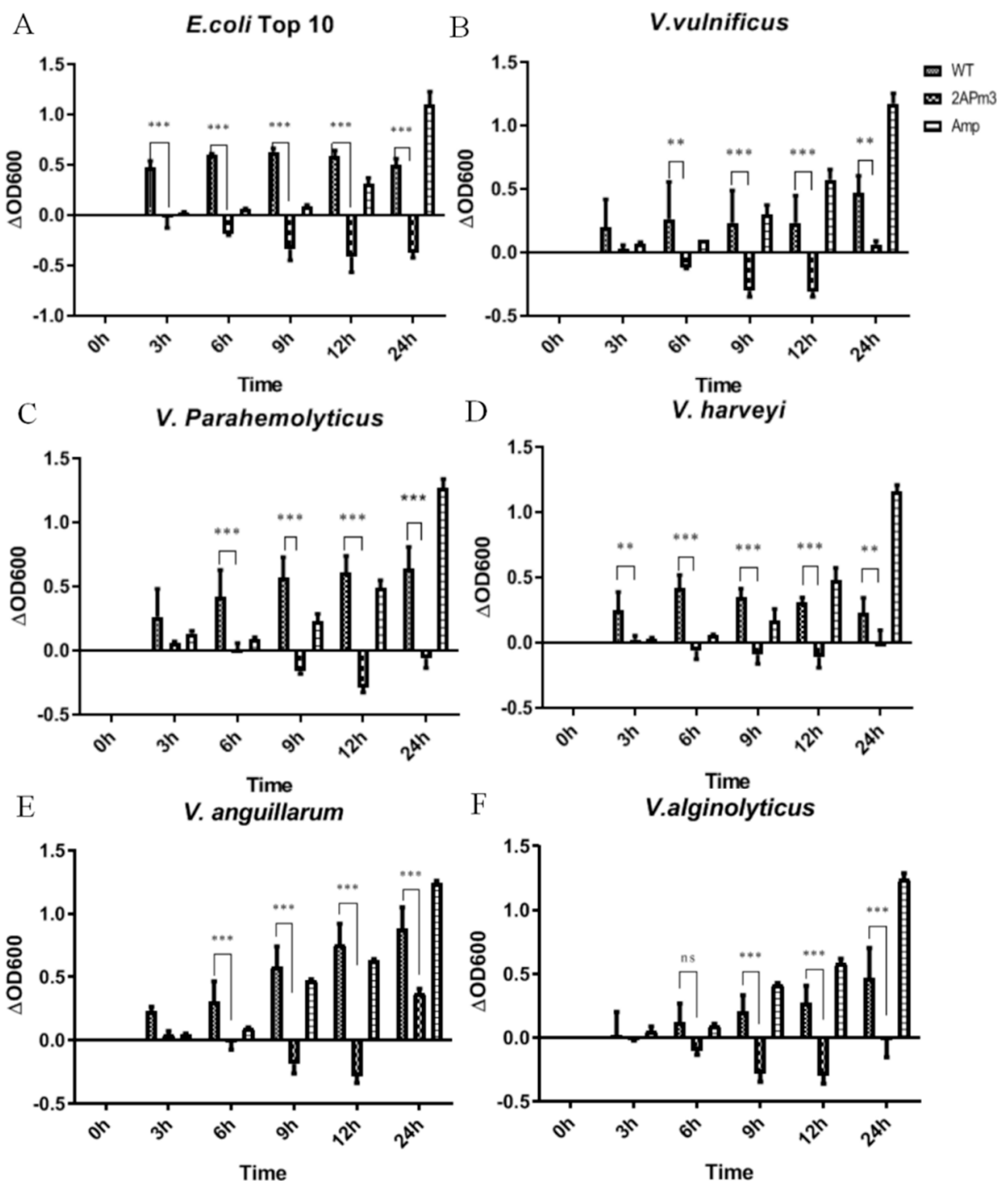

F
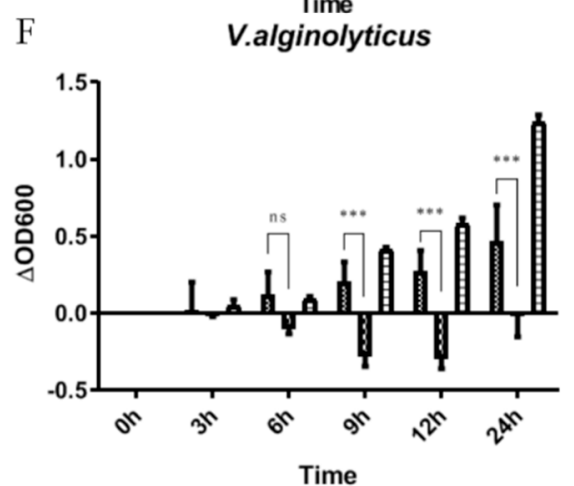

Figure 10. Growth of Gram-negative bacteria under different treatments. Data are statistically analyzed. ${ }^{* *} p<0.001$. ${ }^{* *} p<0.01$. ns, no significant. (A) E. coil Top 10. (B) V. vulnificus. (C) V. parahemolyticus. (D) V. harveyi. (E) V. anguillarum. (F) V. alginolyticus. 


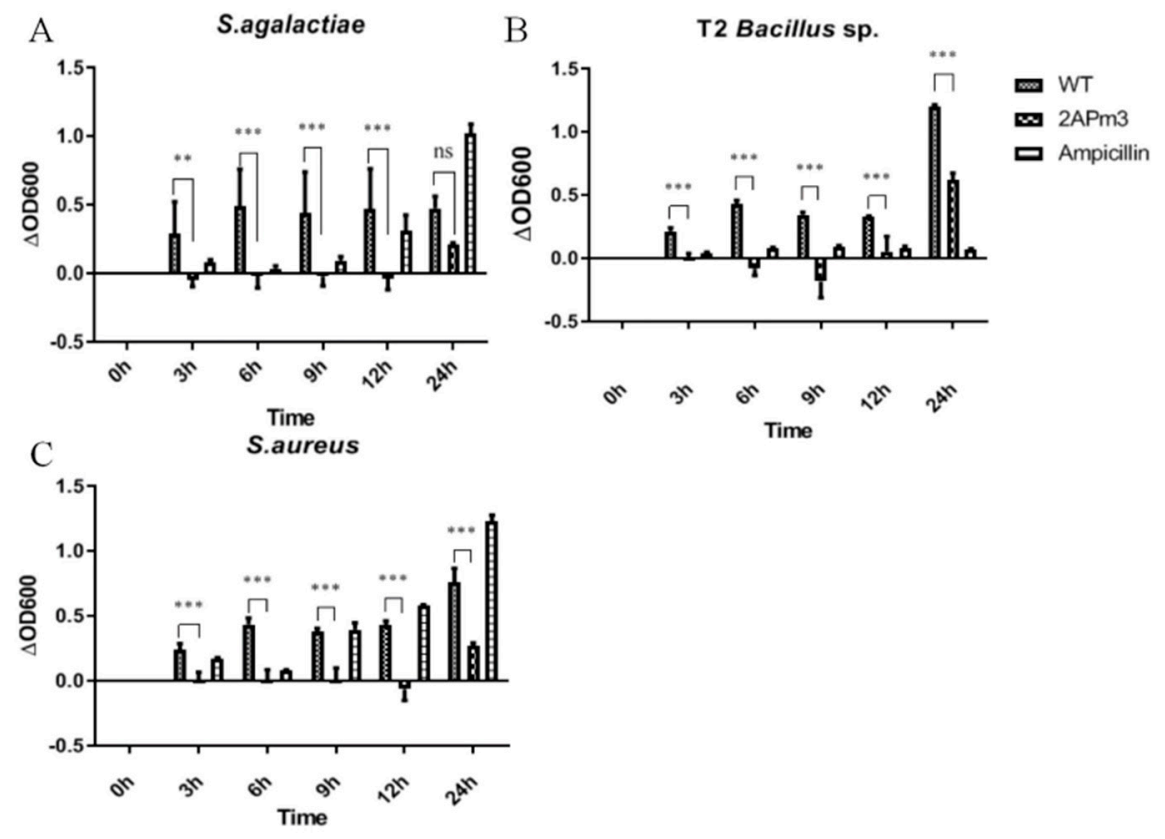

Figure 11. Growth of Gram-positive bacteria under different treatments. Data are statistically analyzed. ${ }^{* * *} p<0.001 .{ }^{* *} p<0.01$. ns, no significant. (A) S. agalactiae. (B) Bacillus sp. T2. (C) S. aureus.

\section{Discussion}

In this study, we designed an expression cassette of Ble-2A-ALFPm 3 to produce the ALFPm3 peptide in C. reinhardtii. With the help of $2 \mathrm{~A}$ peptide, which is a self-cleavage peptide from FMDV $[48,49]$, the ALFPm3 peptide was successfully expressed in C. reinhardtii and released from the Ble-2A-ALFPm3-fused protein with a yield of $0.35 \%$ of total soluble protein. In order to increase the expression level and prevent gene silencing, the ble gene was fused to the N-terminal of the ALFPm3 gene via the 2A peptide, according to Beth A Rasala et al. [41]. The 2A peptide system has been co-expressed with several proteins at a high level, such as the fluorescent protein targeted to various cellular subcompartments [50], secreted xylanases [41], Cpf1 endonuclease [51], and squalene synthase [52]. Here, the ALFPm3 gene was co-introduced into C. reinhardtii with the ble gene. With this expression strategy, we could express the mature peptide of ALFPm3 without its own signal peptide, which was essential for expression in cells. Finally, cALFPm3 could be released from the Ble-2A-ALFPm3 protein and showed a great antimicrobial activity against both Gram-negative bacteria and Gram-positive bacteria. Therefore, this expression strategy was suitable to produce antimicrobial peptides.

Research has indicated that the E. coli system could not be used for expressing active AMPs or high-antimicrobial activity peptide due to the lack of post-protein processing [23-27]. The $P$. pastoris system could over-glycosylate AMPs, which reduced the antimicrobial activity $[28,29]$. Moreover, a lot of materials and energy are required in both E. coli and $P$. pastoris system and a large number of harmful gases are produced, including $\mathrm{CO}_{2}$ [27-29]. On the other hand, with the advantages of rapid growth, high photosynthetic efficiency, and carbon fixation ability, C. reinhardtii as a green microalga has been regarded as a novel host for the production of high-value chemicals and recombinant proteins. Although the productivity was not very high in C. reinhardtii, cALFPm3 showed high antimicrobial activity at a low concentration. The yield of AMPs in C. reinhardtii could reach up to $262 \mathrm{mg} / \mathrm{L}$, as reported by Dong et al. [53]. Moreover, the production of cALFPm3 owned the potentiality to increase its yield with a strong promoter, leaky codon, and Kozak sequence.

It is reported that the ALFPm3 derived from P. pastoris exhibited high antimicrobial activity, especially for Gram-negative bacteria at a low concentration (less than $3 \mu \mathrm{M}$ ) and the Gram-positive bacteria at a higher concentration (between $50 \mathrm{mM}$ and $100 \mathrm{mM}$ ) [30]. Here, compared with P. pastoris-derived ALFPm3, the cALFPm3 showed a higher antimicrobial 
activity and a long-time effect on the tested bacteria within $24 \mathrm{~h}$ at a lower concentration of $0.77 \mu \mathrm{M}$. More encouragingly, most of the tested bacteria hardly grew when incubated with $0.77 \mu \mathrm{M}$ cALFPm 3 within $24 \mathrm{~h}$, which is different from the bacteria that were recovered after $9 \mathrm{~h}$ when treated with ampicillin. Thus, it is possible to reduce the number of antibacterial substances and obtain better antimicrobial effects by using cALFPm3. Moreover, microalgae are easy to cultivate and processing and is recognized as a safe feed additive, showing its great application in the future.

In this work, an expression cassette of ALFPm3 was designed and expressed in C. reinhardtii with high antimicrobial activity. It provides a new way for producing AMPs with high activity and the potential use of AMPs in the aquaculture industry.

\section{Materials and Methods}

\subsection{Algal Strain and Culture Conditions}

C. reinhardtii cell wall-deficient strain CC-849 was purchased from the Chlamydomonas Resource Center (USA), and was cultivated mixotrophically in Tris-Acetate-Phosphate (TAP) liquid medium or TAP agar medium contained $100 \mu \mathrm{g} / \mathrm{mL}$ ampicillin (Biosharp, Anhui, China) at $25^{\circ} \mathrm{C}$ under a continuous light intensity of $100 \mu \mathrm{E} \cdot \mathrm{m}^{-2} \cdot \mathrm{s}^{-1}$. Transgenic Chlamy was selected on the TAP agar plate supplemented with $8 \mu \mathrm{g} / \mathrm{mL}$ zeocin (Invitrogen, CA, USA) and $100 \mu \mathrm{g} / \mathrm{mL}$ ampicillin. Algal cells were cultivated until the cell density reached $1 \times 10^{6}$ cell $/ \mathrm{mL}$. For the heat shock induction, cells were incubated at $40{ }^{\circ} \mathrm{C}$ for $20 \mathrm{~min}$. For high light stress, cells were cultivated under the light intensity of 100 , 200,300 , and $400 \mu \mathrm{E} \cdot \mathrm{m}^{-2} \cdot \mathrm{s}^{-1}$ for $30 \mathrm{~min}$. After each treatment, cells were harvested by centrifugation at $5000 \times g$ for $5 \mathrm{~min}$.

\subsection{Plasmid Construction and Genetic Transformation}

To improve the transformation frequency and enhance hetero-gene expression, the coding sequence of ALFPm3 (Genbank accession: JQ256520) was optimized according to the codon bias of $C$. reinhardtii. The optimized nucleotides were synthesized by AnHui General Biosystem Company (Anhui, China) and then inserted into pH124 vector to obtain the plasmid pH2A-Pm3 (Figure 3). This vector contains HSP70A-RBCS2 fusion promoter, which can be induced by high light and heat shock. The ble gene was fused to the $\mathrm{N}$-terminal of the ALFPm3 gene via the FMDV self-cleavage $2 \mathrm{~A}$ peptide. The constructed plasmid was proliferated in E. coli Top10 on an LB agar plate containing $100 \mu \mathrm{g} / \mathrm{mL}$ ampicillin.

The $C$. reinhardtii transformation was processed using glass-bead method according to recommendations [54]. Briefly, the algal cells were cultivated in $100 \mathrm{~mL}$ TAP liquid medium in an incubator shaker at the condition of $25^{\circ} \mathrm{C}, 100 \mathrm{rpm}$, and continuous light intensity of $100 \mu \mathrm{E} \cdot \mathrm{m}^{-2} \cdot \mathrm{s}^{-1}$ until the cell density was reached to $1 \sim 2 \times 10^{6}$ cell $/ \mathrm{mL}$. Cells were harvested by centrifugation at $5000 \times g$ for $5 \mathrm{~min}$ and resolved with $300 \mu \mathrm{L}$ TAP liquid medium to keep the final density of $2 \times 10^{8} \mathrm{cell} / \mathrm{mL}$. Cell cultures were transferred to a new $1.5 \mathrm{~mL}$ microcentrifuge tube containing $300 \mathrm{mg}$ glass beads $(0.5 \mathrm{~mm}$ in diameter) and $2 \mu \mathrm{g}$ linearized $\mathrm{pH} 2 \mathrm{~A}-\mathrm{Pm} 3$ plasmid. The glass beads were blown gently and vortexed at the highest speed, $2500 \mathrm{rpm}$, for $25 \mathrm{~s}$. Afterward, the supernatant was transferred to a new microcentrifuge tube with $10 \mathrm{~mL}$ TAP liquid medium, cultivated at $25{ }^{\circ} \mathrm{C}$ with a light intensity of $90 \mu \mathrm{E} \cdot \mathrm{m}^{-2} \cdot \mathrm{s}^{-1}$, and shaken continuously at $100 \mathrm{rpm}$ for $22 \mathrm{~h}$. Finally, cells were harvested by centrifugation at $3000 \times g$ for $5 \mathrm{~min}$, resolved with $100 \mu \mathrm{L}$ TAP liquid medium, and spread on the TAP agar medium containing $8 \mu \mathrm{g} / \mathrm{mL}$ zeocin and $100 \mu \mathrm{g} / \mathrm{mL}$ ampicillin. They were cultivated at $25^{\circ} \mathrm{C}$ in an incubator under a continuous light intensity of $100 \mu \mathrm{E} \cdot \mathrm{m}^{-2} \cdot \mathrm{s}^{-1}$ until the green colonies were visible. The number of colonies was recorded and counted as the transformation frequency. Transformation frequency $=$ numbers of colonies $/$ total recipient cells. 


\subsection{Genomic PCR and RT-PCR Analysis}

The green colonies were copied to a new TAP agar medium containing $8 \mu \mathrm{g} / \mathrm{mL}$ zeocin and $100 \mu \mathrm{g} / \mathrm{mL}$ ampicillin, and cultivated for one week. The positive transformants were selected by genomic PCR as described, targeting the ble gene and ALFPm3 gene [55]. For genomic PCR, $1 \times 10^{5}$ cells were harvested and then resuspended in $50 \mu \mathrm{L}$ EDTA solution $(10 \mathrm{mM}, \mathrm{pH} 8.0)$, after which they were incubated in boiling water for $8 \mathrm{~min}$, cooled down on ice for $1 \mathrm{~min}$, and pelleted at $14,000 \times \mathrm{g}$ for $1 \mathrm{~min}$. Finally, one microliter of the extract was used in the $20 \mu \mathrm{L}$ PCR reaction containing a set of primers (Table 1 ) and PCR reaction buffer according to the instruction (Mei5 Biotechnology Co., Ltd, Beijing, China). The PCR program was $95^{\circ} \mathrm{C}$ for $5 \mathrm{~min}, 35$ cycles of $95^{\circ} \mathrm{C}$ for $1 \mathrm{~min}, 56{ }^{\circ} \mathrm{C}$ for $30 \mathrm{~s}, 72{ }^{\circ} \mathrm{C}$ for $30 \mathrm{~s}$, and finally extended at $72{ }^{\circ} \mathrm{C}$ for $5 \mathrm{~min}$. For RT-PCR, Total RNA was extracted by RNA fast 200 Kit (Fastagen, Shanghai, China) and $1 \mu \mathrm{g}$ of the total RNA was used to synthesize the first strand of cDNA by PrimeScript ${ }^{\mathrm{TM}}$ RT reagent Kit with gDNA Eraser (Takara, Dalian, China). Two microliter cDNA was used in a $20-\mu \mathrm{L}$ PCR reaction containing a set of primers (Table 1 ) and reaction buffer according to the manufacturer's instructions (Mei5 Biotechnology Co.,Ltd, Beijing, China). For the RT-PCR, $\beta$-actin was chosen as an internal control (Table 1 ). All PCR products were analyzed by $1 \%$ agarose gel electrophoresis.

Table 1. Sequence of primers used in this study.

\begin{tabular}{clc}
\hline Name & \multicolumn{1}{c}{ Sequence $\left(5^{\prime}-\mathbf{3}^{\prime}\right)$} & Target Gene \\
\hline Ble-F & TTAAATCTAGAAAAATGGCCAG & ble \\
Ble-R & GTCCTGCTCCTCGGCCACG & \\
ALF3-F & AAGTTCACCGTGAAGCCCTAC & ALFPm3 \\
ALF3-R & CTGCTCAGCCACTGGTTCGC & \multirow{2}{*}{-actin } \\
actin-F & ACCCCGTGCTGCTGACTG & \\
actin-R & ACGTTGAAGGTCTCGAACA & \\
\hline
\end{tabular}

\subsection{Protein Extraction and Immunoblot Analysis}

To evaluate the performance of transgenic C. reinhardtii (T-2APm3) on the ALFPm3 production, total protein was extracted and processed on immunoblot analysis. Algal cells were cultivated in TAP liquid medium under constant light intensity of $100 \mu \mathrm{E} \cdot \mathrm{m}^{-2} \cdot \mathrm{s}^{-1}$ until a cell density of $1 \sim 2 \times 10^{6} \mathrm{cell} / \mathrm{mL}$ was reached. Cells were harvested from one milliliter culture and resuspended with $100 \mu \mathrm{L}$ lysis buffer (Solution A:Solution B, 3:2, v/v) (Solution A: $1 \mathrm{M} \mathrm{Na}_{2} \mathrm{CO}_{3} 120 \mu \mathrm{L}, 1 \mathrm{M}$ DTT $120 \mu \mathrm{L}$, deionized water $960 \mu \mathrm{L}$, Cock tail $20 \mu \mathrm{L}$; Solution B: 5\% SDS, 30\% Sucrose). After being shaken at $1200 \mathrm{rpm}$ under room temperature for $10 \mathrm{~min}$, cells were frozen-thawed three times in liquid nitrogen with $3 \mathrm{~min}$ between each repetition. The supernatant was collected at $14,000 \times \mathrm{g}$ for $10 \mathrm{~min}$ at $4{ }^{\circ} \mathrm{C}$ for the following western blot analysis. Briefly, $20 \mu \mathrm{g}$ total protein was separated by $4-20 \%$ SDS-PAGE (Genscrip, New Jersey, USA) and then transferred to a PVDF membrane $(0.2 \mu \mathrm{m}$, Millipore, Massachusetts, USA) activated by $100 \%$ methanol. The membrane was then blocked with blocking buffer ( $5 \%$ non-fat dry milk in TBST $(10 \mathrm{mM}$ Tris, $166 \mathrm{mM} \mathrm{NaCl}$, $\mathrm{pH} 7.4$, contained $0.05 \%$ Tween 20)) for $2 \mathrm{~h}$ at room temperature. The membrane was incubated with the mouse anti-His tag antibody (1:8000) (Agrisera, Vännäs, Sweden) in blocking buffer at $4{ }^{\circ} \mathrm{C}$ overnight right after washed three times with TBST. Afterward, the membrane was incubated with HRP-conjugated goat anti-mouse IgG antibody $(1: 10,000)$ (Beijing Biodragon, Beijing, China) at room temperature for $2 \mathrm{~h}$, and washed with TBST for 3 times. Finally, the membrane was incubated in ECL substrate buffer (Solution A: Solution B, 1:40, v/v) (ThermoScientific, MA, USA) at room temperature for $3 \mathrm{~min}$. The chemiluminescence signal was detected by Odyssey.Fc (Gene Company Limited, HK, China). The $\alpha$-tublin was used as the internal control. The gray values referring protein content were analyzed by Image J software (NIH, Maryland, USA). For calculating the content of target protein, a protein contained $6 \times$ His tag at the concentration of $3.4 \mu \mathrm{g} / \mathrm{mL}$ 
was used as the calibrator. The content of the target protein was calculated by comparing its gray value with that of calibrator.

\subsection{Anti-Bacterial Assay}

For the anti-bacterial assay, the ALFPm3 peptide was prepared as follows. The transgenic Chlamydomonas T-2APm 3 was cultivated in $800 \mathrm{~mL}$ TAP liquid medium under a continuous light intensity of $100 \mu \mathrm{E} \cdot \mathrm{m}^{-2} \cdot \mathrm{s}^{-1}$ until the cell density reached $1 \sim 2 \times 10^{6}$ cell/mL. Cultures were centrifuged at $5000 \times g$ at $4{ }^{\circ} \mathrm{C}$ for $5 \mathrm{~min}$, the supernatant was discarded, and pellets were resuspended with $10 \mathrm{~mL}$ lysis buffer (Solution A: Solution B is 3:2,v/v) (Solution A: $1 \mathrm{M} \mathrm{Na}_{2} \mathrm{CO}_{3} 120 \mu \mathrm{L}, 1 \mathrm{M}$ DTT $120 \mu \mathrm{L}$, deionized water $960 \mu \mathrm{L}$, Cock tail $20 \mu \mathrm{L}$. Solution B: 30\% Sucrose) and shaken at $1200 \mathrm{rpm}$ under room temperature for $10 \mathrm{~min}$. Then cells were frozen and thawed three times in liquid nitrogen with 3 min between each repetition. The supernatant contained ALFPm3 peptide was obtained by centrifugation at $14,000 \times g$ for $10 \mathrm{~min}$ at $4{ }^{\circ} \mathrm{C}$, followed by filtration with $0.22 \mu \mathrm{m}$ filter tip. To investigate the antibacterial activity of peptide extracts, a total of six Gram-negative bacteria $(E$. coli Top 10, Vibrio vulnificus, Vibrio parahemolyticus, Vibrio harveyi, Vibrio anguillarum, and Vibrio alginolyticus) and three Gram-positive bacteria (Streptococcus agalactiae, Bacillus sp $\mathrm{T} 2$, Staphylococcus aureus) were tested. Before the assay, the tested bacteria were cultivated in $5 \mathrm{~mL}$ LB liquid medium under $37^{\circ} \mathrm{C}$ with shaking at $200 \mathrm{rpm}$ overnight. The $500 \mu \mathrm{L}$ cultures were added into $5 \mathrm{~mL}$ fresh LB liquid medium and cultivated at $37{ }^{\circ} \mathrm{C}$ with shaking at $200 \mathrm{rpm}$ for $1 \mathrm{~h}$. Then, the bacteria cultures were diluted by 1000 times using fresh LB medium and $150 \mu \mathrm{L}$ diluted cultures were mixed with $50 \mu \mathrm{L}$ ALFPm3 peptide in 96-well plate. The final concentration of ALFPm3 peptide was $0.7669 \mu \mathrm{M}$. The extracts from wide type C. reinhardtii and $5 \mathrm{mg} / \mathrm{mL}$ ampicillin acted as negative and positive control, respectively. Finally, the mixture of bacteria and ALFPm 3 was incubated at $37^{\circ} \mathrm{C}$ and the OD600 was determined at $0 \mathrm{~h}, 3 \mathrm{~h}, 6 \mathrm{~h}, 9 \mathrm{~h}, 12 \mathrm{~h}$, and $24 \mathrm{~h}$, respectively. The growth rate $(\triangle \mathrm{OD} 600)$ of the bacteria under different treatments was obtained by comparing the OD600 value with that at $0 \mathrm{~h}$.

\subsection{Expression Analysis of ALFPm3 in C. reinhardtii Transformants}

To observe the expression of ALFPm3 in C. reinhardtii, the transgenic Chlamydomonas T-2APm3 was kept constant for 6 months and the total RNA of T-2APm3 was isolated and followed by RT-PCR with primers ALF3-F and ALF3-R. PCR products were analyzed by $1 \%$ agarose gel electrophoresis. The growth curves of non-transgenic $C$. reinhardtii and transgenic $C$. reinhardtii were measured to analyze the effect of ALFPm3 on algae growth. They were cultivated in $100 \mathrm{~mL}$ TAP liquid medium under continuous light intensity of $100 \mu \mathrm{E} \cdot \mathrm{m}^{-2} \cdot \mathrm{s}^{-1}$ with shaking. Cell numbers were counted every day via a hemocytometer measurement.

\subsection{Statistical Analysis}

Each experiment was conducted with three independent replicates. GraphPad Prism 5 was used to perform the statistical analysis and generate figures and tables. Student's t-test was used to calculate the statistical difference between treatments and $p<0.05$ was considered as showing significant differences.

Author Contributions: Conceptualization, C.W.; methodology, C.W., A.L., R.H., and Q.H.; investigation, A.L. and X.L.; data curation, A.L.; writing-original draft preparation, A.L. and C.W.; writing-review and editing, C.W. and H.L.; project administration, C.W. All authors have read and agreed to the published version of the manuscript.

Funding: This work was supported financially by the National key research and development plan special project for synthetic biology (2018YFA0902500), the National Natural Science Foundation of China (31970366), the Shenzhen Scientific Project (JCYJ20190808114216058) and the Guangdong Natural Science Foundation (2019A1515011701).

Institutional Review Board Statement: Not applicable. 


\section{Data Availability Statement: Not applicable.}

Acknowledgments: We thank Yiwen Lin for detecting the ALFPm3 in transgenic C. reinhardtii and Danqiong Huang for revising this article.

Conflicts of Interest: The authors declare no conflict of interest.

\section{References}

1. Durand, G.A.; Raoult, D.; Dubourg, G. Antibiotic discovery: History, methods and perspectives. Int. J. Antimicrob. Agents 2019, 53, 371-382. [CrossRef]

2. López-Montesinos, I.; Domínguez-Guasch, A.; Gómez-Zorrilla, S.; Duran-Jordà, X.; Siverio-Parès, A.; Arenas-Miras, M.; Montero, M.; Redó, L.S.; Grau, S.; Horcajada, J.; et al. Clinical and economic burden of community-onset multidrug-resistant infections requiring hospitalization. J. Infect. 2020, 80, 271-278. [CrossRef]

3. Munita, J.M.; Arias, C.A. Mechanisms of Antibiotic Resistance. Microbiol. Spectr. 2016, 4. [CrossRef]

4. Bhopale, G.M. Antimicrobial Peptides: A Promising Avenue for Human Healthcare. Curr. Pharm. Biotechnol. 2020, 21 , 90-96. [CrossRef]

5. Zasloff, M. Antimicrobial Peptides of Multicellular Organisms: My Perspective. Adv. Exp. Med. Biol. 2019, 1117, 3-6. [CrossRef]

6. Yi, H.-Y.; Chowdhury, M.; Huang, Y.-D.; Yu, X.-Q. Insect antimicrobial peptides and their applications. Appl. Microbiol. Biotechnol. 2014, 98, 5807-5822. [CrossRef]

7. Slavokhotova, A.A.; Shelenkov, A.A.; Andreev, Y.A.; Odintsova, T.I. Hevein-like antimicrobial peptides of plants. Biochemistry 2017, 82, 1659-1674. [CrossRef]

8. Chen, X.; Yi, Y.; Bian, C.; You, X.; Shi, Q. Putative Antimicrobial Peptides in Fish: Using Zebrafish as a Representative. Protein Pept. Lett. 2020, 27, 1059-1067. [CrossRef]

9. Balandin, S.V.; Sheremeteva, E.V.; Ovchinnikova, T.V. Pediocin-Like Antimicrobial Peptides of Bacteria. Biochemistry 2019, 84, 464-478. [CrossRef]

10. Raeder, S.B.; Sandbakken, E.T.; Nepal, A.; Løseth, K.; Bergh, K.; Witsø, E.; Otterlei, M. Novel Peptides Targeting the $\beta$-Clamp Rapidly Kill Planktonic and Biofilm Staphylococcus epidermidis Both in vitro and in vivo. Front. Microbiol. 2021, 12. [CrossRef]

11. Wang, Y.; Zhang, J.; Sun, Y.; Sun, L. A Crustin from Hydrothermal Vent Shrimp: Antimicrobial Activity and Mechanism. Mar. Drugs 2021, 19, 176. [CrossRef]

12. Tornesello, A.L.; Borrelli, A.; Buonaguro, L.; Buonaguro, F.M.; Tornesello, M.L. Antimicrobial Peptides as Anticancer Agents: Functional Properties and Biological Activities. Molecules 2020, 25, 2850. [CrossRef]

13. Deslouches, B.; Di, Y.P. Antimicrobial peptides with selective antitumor mechanisms: Prospect for anticancer applications. Oncotarget 2017, 8, 46635-46651. [CrossRef]

14. Hancock, R.E.; Diamond, G. The role of cationic antimicrobial peptides in innate host defences. Trends Microbiol. 2000, 8, 402-410. [CrossRef]

15. Tanaka, S.; Nakamura, T.; Morita, T.; Iwanaga, S. Limulus anti-LPS factor: An anticoagulant which inhibits the endotoxinmediated activation of Limulus coagulation system. Biochem. Biophys. Res. Commun. 1982, 105, 717-723. [CrossRef]

16. Zhou, L.; Li, G.; Jiao, Y.; Huang, D.; Li, A.; Chen, H.; Liu, Y.; Li, S.; Li, H.; Wang, C. Molecular and antimicrobial characterization of a group G anti-lipopolysaccharide factor (ALF) from Penaeus monodon. Fish. Shellfish. Immunol. 2019, 94, 149-156. [CrossRef]

17. Soonthornchai, W.; Chaiyapechara, S.; Klinbunga, S.; Thongda, W.; Tangphatsornruang, S.; Yoocha, T.; Jarayabhand, P.; Jiravanichpaisal, P. Differentially expressed transcripts in stomach of Penaeus monodon in response to AHPND infection. Dev. Comp. Immunol. 2016, 65, 53-63. [CrossRef]

18. Tharntada, S.; Somboonwiwat, K.; Rimphanitchayakit, V.; Tassanakajon, A. Anti-lipopolysaccharide factors from the black tiger shrimp, Penaeus monodon, are encoded by two genomic loci. Fish. Shellfish. Immunol. 2008, 24, 46-54. [CrossRef]

19. Methatham, T.; Boonchuen, P.; Jaree, P.; Tassanakajon, A.; Somboonwiwat, K. Antiviral action of the antimicrobial peptide ALFPm3 from Penaeus monodon against white spot syndrome virus. Dev. Comp. Immunol. 2017, 69, 23-32. [CrossRef] [PubMed]

20. Jaree, P.; Tassanakajon, A.; Somboonwiwat, K. Effect of the anti-lipopolysaccharide factor isoform 3 (ALFPm3) from Penaeus monodon on Vibrio harveyi cells. Dev. Comp. Immunol. 2012, 38, 554-560. [CrossRef]

21. Ponprateep, S.; Tharntada, S.; Somboonwiwat, K.; Tassanakajon, A. Gene silencing reveals a crucial role for anti-lipopolysaccharide factors from Penaeus monodon in the protection against microbial infections. Fish. Shellfish. Immunol. 2012, 32, 26-34. [CrossRef]

22. Zhou, L.; Li, G.; Li, A.; Jiao, Y.; Li, S.; Huang, J.; Yang, L.; Wang, C. Characterization of a group D anti-lipopolysaccharide factor (ALF) involved in anti-Vibrio response in Penaeus monodon. Fish. Shellfish. Immunol. 2019, 89, 384-392. [CrossRef] [PubMed]

23. Gong, G.-L.; Wei, Y.; Wang, Z.-Z. Functional expression, purification, and antimicrobial activity of a novel antimicrobial peptide MLH in Escherichia coli. Prep. Biochem. Biotechnol. 2018, 48, 57-63. [CrossRef]

24. Corrales-García, L.L.; Serrano-Carreón, L.; Corzo, G. Improving the heterologous expression of human $\beta$-defensin 2 (HBD2) using an experimental design. Protein Expr. Purif. 2020, 167, 105539. [CrossRef]

25. Yi, T.; Sun, S.; Huang, Y.; Chen, Y. Prokaryotic expression and mechanism of action of $\alpha$-helical antimicrobial peptide A20L using fusion tags. BMC Biotechnol. 2015, 15, 69. [CrossRef]

26. Ishida, H.; Nguyen, L.T.; Gopal, R.; Aizawa, T.; Vogel, H.J. Overexpression of Antimicrobial, Anticancer, and Transmembrane Peptides inEscherichia colithrough a Calmodulin-Peptide Fusion System. J. Am. Chem. Soc. 2016, 138, 11318-11326. [CrossRef] 
27. Su, G.; Tang, F.; Chen, D.; Yu, B.; Huang, Z.; Luo, Y.; Mao, X.; Zheng, P.; Yu, J.; Luo, J.; et al. Expression, Purification and Characterization of a Novel Antimicrobial Peptide: Gloverin A2 from Bombyx mori. Int. J. Pept. Res. Ther. 2019, 25, 827-833. [CrossRef]

28. Cao, J.; De La Fuente-Nunez, C.; Ou, R.W.; Torres, M.D.T.; Pande, S.G.; Sinskey, A.J.; Lu, T.K. Yeast-Based Synthetic Biology Platform for Antimicrobial Peptide Production. ACS Synth. Biol. 2018, 7, 896-902. [CrossRef]

29. Li, X.; Fan, Y.; Lin, Q.; Luo, J.; Huang, Y.; Bao, Y.; Xu, L. Expression of chromogranin A-derived antifungal peptide CGA-N12 in Pichia pastoris. Bioengineered 2020, 11, 318-327. [CrossRef] [PubMed]

30. Somboonwiwat, K.; Marcos, M.; Tassanakajon, A.; Klinbunga, S.; Aumelas, A.; Romestand, B.; Gueguen, Y.; Boze, H.; Moulin, G.; Bachère, E. Recombinant expression and anti-microbial activity of anti-lipopolysaccharide factor (ALF) from the black tiger shrimp. Dev. Comp. Immunol. 2005, 29, 841-851. [CrossRef]

31. Tang, T.; Liu, J.; Li, S.; Li, H.; Liu, F. Recombinant expression of an oriental river prawn anti-lipopolysaccharide factor gene in Pichia pastoris and its characteristic analysis. Fish. Shellfish. Immunol. 2020, 98, 414-419. [CrossRef]

32. Prabhu, A.A.; Boro, B.; Bharali, B.; Chakraborty, S.; Dasu, V.V. Gene and process level modulation to overcome the bottlenecks of recombinant proteins expression in Pichia pastoris. Curr. Pharm. Biotechnol. 2018, 18, 1200-1223. [CrossRef]

33. Puxbaum, V.; Mattanovich, D.; Gasser, B. Quo vadis? The challenges of recombinant protein folding and secretion in Pichia pastoris. Appl. Microbiol. Biotechnol. 2015, 99, 2925-2938. [CrossRef]

34. Rabert, C.; Weinacker, D., Jr.; Pessoa, A.; Farías, J.G. Recombinants proteins for industrial uses: Utilization of Pichia pastoris expression system. Braz. J. Microbiol. 2013, 44, 351-356. [CrossRef]

35. Zhang, M.-P.; Wang, M.; Wang, C. Nuclear transformation of Chlamydomonas reinhardtii: A review. Biochimie 2021, 181, 1-11. [CrossRef]

36. Kim, Y.H.; Kwon, S.G.; Bae, S.J.; Park, S.J.; Im, J. Optimization of the droplet electroporation method for wild type Chlamydomonas reinhardtii transformation. Bioelectrochemistry 2019, 126, 29-37. [CrossRef] [PubMed]

37. Purton, S. Tools and Techniques for Chloroplast Transformation of Chlamydomonas. Adv. Exp. Med. Biol. 2007, 616, 34-45. [CrossRef] [PubMed]

38. Sandoval-Vargas, J.M.; Jiménez-Clemente, L.A.; Macedo-Osorio, K.S.; Oliver-Salvador, M.C.; Fernández-Linares, L.C.; DuránFigueroa, N.V.; Badillo-Corona, J.A. Use of the ptxD gene as a portable selectable marker for chloroplast transformation in Chlamydomonas reinhardtii. Mol. Biotechnol. 2019, 61, 461-468. [CrossRef]

39. LaRosa, V.; Remacle, C. Transformation of the mitochondrial genome. Int. J. Dev. Biol. 2013, 57, 659-665. [CrossRef]

40. Merchant, S.S.; Prochnik, S.E.; Vallon, O.; Harris, E.H.; Karpowicz, S.J.; Witman, G.B.; Terry, A.; Salamov, A.; Fritz-Laylin, L.K.; Maréchal-Drouard, L.; et al. The Chlamydomonas Genome Reveals the Evolution of Key Animal and Plant Functions. Science 2007, 318, 245-250. [CrossRef]

41. Rasala, B.A.; Lee, P.A.; Shen, Z.; Briggs, S.P.; Mendez, M.; Mayfield, S.P. Robust Expression and Secretion of Xylanase1 in Chlamydomonas reinhardtii by Fusion to a Selection Gene and Processing with the FMDV 2A Peptide. PLoS ONE 2012, 7, e43349. [CrossRef] [PubMed]

42. Soria-Guerra, R.E.; Ramírez-Alonso, J.I.; Ibáñez-Salazar, A.; Govea-Alonso, D.O.; Paz-Maldonado, L.M.T.; Bañuelos-Hernández, B.; Korban, S.S.; Rosales-Mendoza, S. Expression of an HBcAg-based antigen carrying angiotensin II in Chlamydomonas reinhardtii as a candidate hypertension vaccine. Plant Cell Tissue Organ Cult. 2014, 116, 133-139. [CrossRef]

43. Gregory, J.A.; Li, F.; Tomosada, L.M.; Cox, C.J.; Topol, A.B.; Vinetz, J.M.; Mayfield, S. Algae-Produced Pfs25 Elicits Antibodies That Inhibit Malaria Transmission. PLoS ONE 2012, 7, e37179. [CrossRef] [PubMed]

44. Barahimipour, R.; Neupert, J.; Bock, R. Efficient expression of nuclear transgenes in the green alga Chlamydomonas: Synthesis of an HIV antigen and development of a new selectable marker. Plant. Mol. Biol. 2016, 90, 403-418. [CrossRef] [PubMed]

45. Liang, Z.-C.; Liang, M.-H.; Jiang, J.-G. Transgenic microalgae as bioreactors. Crit. Rev. Food Sci. Nutr. 2020, 60, 3195-3213. [CrossRef]

46. Rasala, B.A.; Mayfield, S.P. The microalgaChlamydomonas reinhardtiias a platform for the production of human protein therapeutics. Bioeng. Bugs 2011, 2, 50-54. [CrossRef]

47. Schroda, M. Good News for Nuclear Transgene Expression in Chlamydomonas. Cells 2019, 8, 1534. [CrossRef]

48. De Felipe, P.; Izquierdo, M. Construction and characterization of pentacistronic retrovirus vectors. J. Gen. Virol. 2003, 84, 1281-1285. [CrossRef]

49. Agca, C.; Seye, C.; Benson, C.M.K.; Rikka, S.; Chan, A.W.; Weisman, G.A.; Agca, Y. Development of a Novel Transgenic Rat Overexpressing the P2Y2 Nucleotide Receptor Using a Lentiviral Vector. J. Vasc. Res. 2009, 46, 447-458. [CrossRef]

50. Rasala, B.A.; Barrera, D.J.; Ng, J.; Plucinak, T.M.; Rosenberg, J.N.; Weeks, N.P.; Oyler, G.A.; Peterson, T.C.; Haerizadeh, F.; Mayfield, S.P. Expanding the spectral palette of fluorescent proteins for the green microalgaChlamydomonas reinhardtii. Plant. J. 2013, 74, 545-556. [CrossRef]

51. Dong, B.; Hu, H.-H.; Li, Z.-F.; Cheng, R.-Q.; Meng, D.-M.; Wang, J.; Fan, Z.-C. A novel bicistronic expression system composed of the intraflagellar transport protein gene ift25 and FMDV 2A sequence directs robust nuclear gene expression in Chlamydomonas reinhardtii. Appl. Microbiol. Biotechnol. 2017, 101, 4227-4245. [CrossRef] [PubMed]

52. Plucinak, T.M.; Horken, K.M.; Jiang, W.; Fostvedt, J.; Nguyen, S.T.; Weeks, D.P. Improved and versatile viral 2A platforms for dependable and inducible high-level expression of dicistronic nuclear genes in Chlamydomonas reinhardtii. Plant. J. 2015, 82, 717-729. [CrossRef] 
53. Dong, B.; Cheng, R.-Q.; Liu, Q.-Y.; Wang, J.; Fan, Z.-C. Multimer of the antimicrobial peptide Mytichitin-A expressed in Chlamydomonas reinhardtii exerts a broader antibacterial spectrum and increased potency. J. Biosci. Bioeng. 2018, 125, 175-179. [CrossRef]

54. Neupert, J.; Shao, N.; Lu, Y.; Bock, R. Genetic Transformation of the Model Green Alga Chlamydomonas reinhardtii. In Advanced Structural Safety Studies; Springer Science and Business Media LLC: Berlin/Heidelberg, Germany, 2012; Volume 847, pp. 35-47.

55. Cao, M.; Fu, Y.; Guo, Y.; Pan, J. Chlamydomonas (Chlorophyceae) colony PCR. Protoplasma 2009, 235, 107-110. [CrossRef] [PubMed] 